\title{
Realizacja idei ruchu bolońskiego w szkolnictwie wyższym w Wielkiej Brytanii. Brytyjski upór czy pozostałości imperialnej dominacji?
}

o może mieć ze sobą wspólnego imperializm i szkolnictwo wyższe? Wydaje się że niewiele, ale jednak jeśli przyjrzeć się byłemu państwu kolonialnemu, a mianowicie Wielkiej Brytanii, to możemy z łatwością zauważyć to, do czego żaden młody Brytyjczyk się nie przyzna lub nie będzie rozumiał, a co wciąż pozostaje dumą starszego pokolenia wysp brytyjskich. Są to imperialne pozostałości w sposobie działania i bycia wobec innych krajów.

Imperializm, według The dictionary of Human Geography, jest utworzeniem i utrzymywaniem nierówności ekonomicznych, kulturalnych i terytorialnych relacji, zwykle pomiędzy państwami i często $\mathrm{w}$ formie imperium, bazującym na dominacji i poddaniu ${ }^{1}$. Imperializm najczęściej można opisać poprzez geograficzne podboje i domeny, tak jak np. Imperium Rzymskie, Imperium Mongolskie, Imperium Hiszpańskie czy choćby ostatnie Imperium Stanów Zjednoczonych i Chin. Termin ten jed-

D. Gregory (red.), The dictionary of Human Geography (5th edition), Wiley-Blackwell 2009, p. 373. 
nak również z łatwością poddaje się operacjonalizacji w odniesieniu do dziedzin takich jak: wiedza, przekonania, wartości i wiara. Budowanie strefy wpływów na tych obszarach jest dużo trudniejsze niż podbój militarny nowych terenów, ale jest nieodzowne przy każdego rodzaju ekspansji lub działaniu w poczuciu wyższości nad innymi jednostkami, grupami lub narodami.

Nie zawsze kraj (naród, państwo), które podbijało militarnie w przeszłości inne narody, wprowadzało swój system wartości. Wiele jest przykładów z historii Świata pokazujących nam, że podbite ekonomicznie i siłowo kraje, tak jak Grecja, były na dużo wyższym poziomie rozwoju i przekazywały najeźdźcom swoje osiągnięcia. W ten sposób same stawały się 'intelektualnymi najeźdźcami,' a imperia, takie jak Rzym, miały możliwość działać efektywniej i „estetyczniej” przy pomocy greckiej myśli filozoficznej i kulturze.

Wielka Brytania jest natomiast przykładem kraju, który podbijając, przekazywał swoje zdobycze cywilizacyjne narodom, z reguły pod wieloma względami słabiej rozwiniętym. Ta terytorialna i intelektualna ekspansja narodu brytyjskiego toczyła się nieprzerwanie przez setki lat i ugruntowała w nim historyczne poczucie niesienia światła do 'ciemnych zakątków’ globu. To poczucie i przywiązanie do posiadania łatwego dostępu do nowoczesnej myśli i wynalazków sprawiło, że trzeba by wielu pokoleń post-imperialnych, aby zdano sobie sprawę, iż nie wszystko co najlepsze wymyśla się nad Tamizą.

Kiedy próbujemy spojrzeć na system edukacji w szkołach wyższych w Europie obecnie, a przypomnimy sobie jak wyglądał on 10-20 lat temu, to trudno się oprzeć przekonaniu, iż cały system boloński jest, jeśli można to tak określić, „domodelowywany” do brytyjskiego. Z pewością jest w nim wiele cech pozytywnych, które można było przetransplantować na inne "grunty", ale jak i w medycynie, tak i w tym przypadku, może to powodować tzw. odrzuty ${ }^{2}$. Strajki przeciw systemowi punktowemu lub po prostu przeciw 'systemowi bolońskiemu' były dla mnie tego naocznym przykładem podczas pobytu w Uniwersytecie Bielefeld w listopadzie 2009 r. ${ }^{3}$ Widok studentów siedzących na głównych salach wykładowych i okupujących je przez tydzień, na znak protestu wobec stanu szkolnictwa w Niemczech a pośrednio również w Europie, zaszokował mnie niezmiernie. Kompromitujące było również usunięcie ich z terenu uczelni

http://www.wiadomosci24.pl/artykul/we_are_not_human_capital_kolejne_ strajki_w_niemczech_116226.html.

http://bildungsstreik-bielefeld.de/?p=382. 
i wywiezienie policyjnymi autami. Zastanawiające jest w tym wypadku, dlaczego ludzie, w interesie których edukacja na wyższym poziomie jest reformowana, tak się jej opierają? Czy coś w tym nowym systemie jest nie tak, czy to tylko normalna reakcja młodego pokolenia na zmiany?

Mimo tych wielu wątpliwości, warto - po pierwsze - zwrócić uwagę jak działa system boloński. Jest on stosowany w tej formie, choć bez nazwy „system boloński”, już od 50 lat w Zjednoczonym Królestwie Wielkiej Brytanii. Jak wcześniej pisałem, to z wysp brytyjskich wychodzą najczęstsze propozycje reform systemów europejskiego szkolnictwa wyższego i dlatego warto staranniej przyjrzeć się temu, jak on tam działa.

Korzenie idei Ruchu Bolońskiego w Europie sięgają zapewne czasów średniowiecza, ale początek nas najbardziej nurtujących spraw i działań stron politycznych oraz ruchów akademickich można umiejscowić w roku 1988, kiedy to 18 września, w Bolonii właśnie, rektorzy kilkuset uczelni europejskich podpisali tzw. Magna Charta Universitatum czyli Wielką Kartę Uniwersytetów Europejskich, sygnowaną również przez przedstawiciela z Uniwersytetu Mikołaja Kopernika, a która mówiła (dość ogólnie) o współpracy środowisk i instytucji akademickich państw europejskich ${ }^{4}$. Kolejnym krokiem na drodze do ukierunkowanego zbliżania się (konwergencji) europejskich szkół wyższych była Konwencja z 1997 r. 'o uznawaniu kwalifikacji wyższego wykształcenia w regionie europejskim’, zwana Lizbońską .

Po dziesięciu latach żywej i pełnej obaw o wykształcenie Europejczyków pracy oraz w obliczu prześcigających Europę, azjatyckich i amerykańskich rynków zatrudnienia, postanowiono wzmocnić możliwości zdobywania zawodu i wykształcenia na Starym Kontynencie. W dniu 25 maja 1998 roku, w Paryżu, na słynnym Uniwersytecie Sorbonne, w czasie trwających uroczystości 750-lecia tego ośrodka wiedzy, spotkali się ministrowie edukacji z Niemiec, Wlk. Brytanii, Francji i Włoch, i podpisali deklarację o współpracy tychże państw, a zarazem każdego innego państwa europejskiego, które by chciało umacniać pozycję Europy w świecie poprzez doskonalenie i modernizowanie kształcenia dla swoich obywateli ${ }^{6}$. Sorbonne Joint Declaration dotyczy 'harmonizacji architektury europej-

A. Lutrzykowski, Między Bolonią a Bergen (1988-2005), Bydgoszcz 2006, s. 13.

Ibidem, s. 18 (oraz http://www.europeunit.ac.uk/sites/europe_unit2/eu_policy education/lisbon_strategy.cfm).

Ibidem, s. 62; Sorbonne Joint Declaration. Joint declaration on harmonization of the architecture of the European higher education system (oraz http://www.bmbf.de/ pub/sorbonne_declaration.pdf). 
skiego systemu szkolnictwa wyższego'. Ze strony Zjednoczonego Królestwa podpis pod tą deklaracją złożyła Baronowa Tessa Blackstone.

Zasadniczym celem procesu bolońskiego jest ustanowienie jednolitego trój-cyklowego systemu nauczania szkół wyższych umożliwiającego uzyskanie tytułów zawodowych licencjata i magistra magistra oraz stopnia doktora lub inaczej badacza nauk. Cel ten wyznaczono w najważniejszej z tych wszystkich - Deklaracji Bolońskiej z 18-19 czerwca 1999r. Innym z zamiarów podpisujących te deklarację, europejskich ministrów edukacji, było podniesienie prestiżu uczelni wyższych na Starym kontynencie do, jeśli to możliwe, porównywalnego dla reszty Świata poziomu.

W kręgach uniwersytetów brytyjskich mówi się, że system ten był unikalny na wyspach brytyjskich i nie występował poza nimi, zwłaszcza jeśli chodzi o możliwość normalnego skończenia studiów po 3 roku i jako 'Bachelor' poszukiwania pracy. Co do unikalności nie jest to do końca prawdą, gdyż i w Polsce podobne podziały istniały. Jednakże to, że tacy absolwenci byli i są na Zachodzie traktowani przez pracodawców bez żadnych 'punktów ujemnych' z powodu braku tytułu magistra, jest mimo podobieństw z polskim systemem czymś aktrakcyjniejszym dla konkretnego kandydata do pracy. Dla studentów brytyjskch, zdobycie tytułu Masters, czyli odpowiednika polskiego tytułu magistra, nie ma na rynku pracy praktycznie żadnego znaczenia. Studia drugiego stopnia są najczęściej wybierane, jeśli konkretna osoba myśli o kontynuacji pracy naukowej. Dlatego napisanie 'Thesis' czyli naszej (polskiej) pracy magisterskiej jest dobrym wstępem do PhD, czyli studiów 3-ego cyklu zwanych doktoranckimi.

Obecne głosy w prasie brytyjskiej wyraźnie wskazują na zagrożenie ze strony procesu bolońskiego, dla systemu szkolnictwa wyższego na wyspach. Niebezpieczeństwo upatruje się właśnie w tak zwanych 10-ciu Celach Procesu Bolońskiego. Według tych krytyków, przyjęcie 'Systemu łatwo czytelnych i porównywalnych stopni’ dla całej Europy sprawia, że Brytania może stracić z powodu odpływu studentów zagranicznych, ze względu na możliwość wyboru innego, równie szybko kształcącego kra$\mathrm{ju}^{7}$. Inna sprawa, że system łatwo porównywalnych stopni nie jest jeszcze zupełnie wdrożony ze względu na upór obu stron co do długości studiów 2-ego stopnia, gdyż jeden rok brytyjskiego nauczania pozwalającego zdobyć tytuł magistra, to dla niektórych profesorów z kontynentu rzecz niemożliwa do wykonania i zarazem nie do przyjęcia. Jakby tego było mało, Brytyjczycy od paru już lat wypróbowują w niektórych uczelniach - dwu-

http://www.guardian.co.uk/education/2008/may/22/highereducation.uk. 
letnie przyspieszone studia licencjackie. Jest to bezpośrednie uderzenie w ustalone przez ministrów edukacji w Deklaracji Bolońskiej z 1999 tzw. Action Lines czyli już nadmienianych Celów do Wykonania, gdzie jest wyraźnie mowa o pierwszym co najmniej 3-letnim cyklu studiów. W mniemaniu innowatorów brytyjskich, a zwłaszcza tamtejszych pracodawców i niektórych studentów, jest to odpowiednia metoda na szybkie wystartowanie do pracy i mniejszy dług po studiach, choć wiąże się oczywiście $\mathrm{z}$ brakiem okresu wakacji oraz bardzo dużym tempem zajęć i zaliczeń ${ }^{8}$.

Inne różnice widoczne są w systemie premiowania studenta punktami zwany skrótowo ECTS. System kontynentalny (w tym polski) różni się od brytyjskiego głównie pod dwoma względami. Pierwszy to ilość punktów przyznawanych za semestr czy rok nauki. Na kontynecie dominuje 60 punktów za rok czyli po 30 za semestr, a na wyspach brytyjskich ta liczba jest większa i wynosi 60 punktów za semestr czyli 120 za rok. Nie jest to taki duży problem, gdyż poradzono sobie z nim poprzez proste mnożenie ilości punktów przez dwa u studenta przyjeżdżającego do Brytanii, a dzielenie na pół jeśli student wyjeżdża z wysp do innego kraju. Istnieje jednak druga ważniejsza różnica, a mianowicie ilość lat drugiego cyklu studiowania, czyli magisterskiego. W większości państw są to dwa lata, tymczasem brytyjskie szkolnictwo, jak wyżej podkreślałem, z rozmachem wdrożyło jednoroczne studia magisterskie. Na powątpiewanie ze strony profesorów czy znanych osobistości z innych państw Brytyjczycy odpowiadają jasno, iż dla nich liczy się to jaki jest wynik nauki studenta, a nie ilość godzin spędzonych na uczelni. Ogromnym problemem są również strukturalne i biurokratyczne zahamowania i obawy przed pełnym respektowaniem studiowania na rodzimej uczelni w porównaniu ze studiowaniem za granicą ${ }^{9}$. Studenci bywa, że mają kłopoty z udokumentowaniem liczby uzyskanych punktów, które by można było w pełni włączyć do ich dotychczasowej 'kariery'. To rodzi obawy co do możliwości uznania tytułu zawodowego lub stopnia naukowego, co może utrudnić możliwość znalezienia pracy. Z tego też względu Europejski Oddział Wyższego Wykształcenia Wielkiej Brytanii (UK Europe Unit) i ich partnerzy na wyspach (czyli uniwersytety, fundacje, rząd) starają się wpłynąc na odpowiednie dopasowanie systemu ECTS do celów jakie ma spełnić w przyszłości dla

Wywiad z Dyrektor Biura Uczenia, Nauczania i Jakości (Head of the Learning, Teaching and Quality Office )na Uniwersytecie Wschodniej Anglii w Norwich - Allison Rhodes przeprowadzony 5 lutego 2010r (arch. własne).

Reakcja tzw. UK Europe Unit na konieczność zwiększenia mobilności w ramach systemu bolońskiego (The future of UK student mobility - a Europe Unit analysis); http:// europeunit.ac.uk/sites/europe_unit2/resources/EuropeUnitMobilityDocument.pdf. 
Europy, czyli stać się uniwersalnym narzędziem punktowania we wszystkich państwach członkowskich procesu.

Spójrzmy teraz na mobilność brytyjskich studentów w porównaniu z mobilnością reszty Europy, gdzie głównym programem, w ramach którego przemieszczają się studenci, wciąż pozostaje zaakceptowany przez państwa europejskie w 1987 ERASMUS. Na podstawie dziewiątego już raportu wydanego przez Uniwesytety Wlk. Brytanii we wrześniu 2009, a dotyczącego sytuacji kształcenia na poziomie wyższym, możemy zauważyć, że wyspy brytyjskie skutecznie przyciągają studentów z całego świata. Jeśliby jednak skupić się jedynie na pańswach procesu bolońskiego to wygląda to następująco:

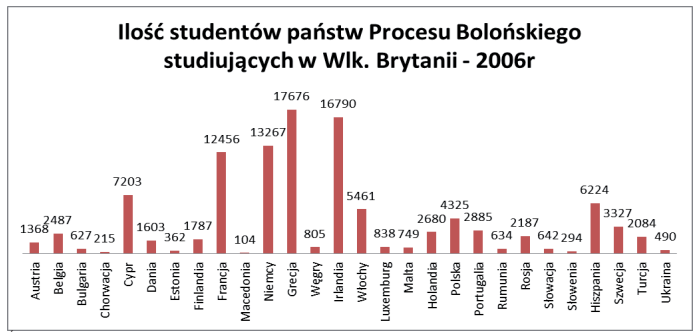

Źródło: Universities UK, Patterns of higher education institutions in the UK: Ninth report s. 96 (opr. własne).

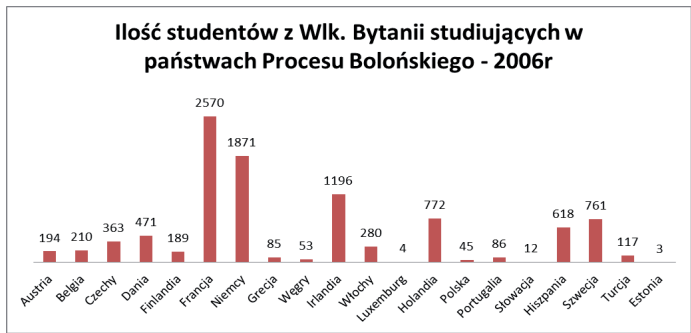

Źródło: Universities UK, Patterns of higher education institutions in the UK: Ninth report s. 9396 (opr. własne). 
Jak widać z powyższych diagramów liczba studentów, którzy przyjeżdżają na wyspy, czyli 109570 osób, zdecydowanie przewyższa liczbę wyjeżdżajacych w poszukiwaniu wiedzy na kontynencie. W roku 2006 było to jedynie 9900 osób. Ten niekorzystny obraz w relacjach studentów wyjeżdżających do przyjeżdżających jest po pierwsze, i najważniejsze, wynikiem „niedouczenia” językowego Brytyjczyków. O tym się mówi w całym społeczeństwie, od zwykłego pracownika po profesorów. Nie wytłumaczy tego już fakt, że wiele narodowości Europy i pozostałych państw świata również, postrzega język angielski za drugi po języku ojczystym. Ten stan już się jednak powoli zmienia i Ci,którzy używają jedynie angielskiego, zaczynają to rozumieć. Usunięcie w Zjednoczonym Królestwie obowiązkowego języka obcego z tzw. GSCE czyli Generalnego Certyfikatu Gimnazjalnej Edukacji, a wprowadzenie go do szkół podstawowych w ostatnich latach, jest ogólnie nie rozumiane w społeczeństwie i w większości nie akceptowane ${ }^{10}$.

Są jednak i inne trudności, które hamują wyjazdy do uniwersytetów europejskich, jak na przykład trudności finansowe i brak jakichkolwiek informacji na temat możliwości studiowania za granicą ${ }^{11}$. Jest to o tyle zrozumiałe, że ten kraj, choć wyda się to paradoksalne, jest mocniej związany ze swoimi byłymi koloniami niż z kontynentem. Z tego też powodu liczba studentów chętnych na wyjazd do Australii, Kanady czy USA bynajmniej nie maleje, co wskazuje na wybieranie kierunku już znanego czy to rodzicom, profesorom czy po prostu znajomym studentom. Aby zwiększyć mobilność brytyjskich żaków, w obszarze państw członkowskich procesu bolońskiego, zaplanowano liczne akcje reklamowe promujące takie wyjazdy oraz umożliwiające uzyskanie dofinansowania oraz pomocy przy zapewnieniu zatrudnienia dla studentów. Oprócz tego coraz częściej spotyka się wypowiedzi i komentarze pracodawców i urzędów statystycznych jednoznacznie twierdzących, że przy wyborze pracownika i wielu kandydatach doświadczenie pracy i studiowanie za granicą ma duże znaczenie.

Uniwersytety Wielkiej Brytanii nie traktowały od razu tego procesu jako większych możliwości dla swoich studentów, ze względu na ich zdaniem, całkiem widoczną konieczność dostosowania się kontynental-

10 Reklamowanie wymiany studenckiej w instytucjach wyższego kształcenia. (Promotion of mobility on HEI web-sites) http://www.hefce.ac.uk/pubs/hefce/2004/04_30/04_30gi. pdf.

11 http://europeunit.ac.uk/sites/europe_unit2/resources/EuropeUnitMobilityDocument.pdf. 
nej edukacji szkół wyższych do wysp brytyjskich, zwłaszcza w praktyce dzielenia studiów na etap licencjacki (Bachelors Degree) i magisterski (Masters Degree), które w takiej formie istniały w Zjednoczonym Królestwie od połowy XX wieku ${ }^{12}$. Jednakże zmiany jakie następowały w Europie kontynentalnej zmusiły również i Brytyjczków do żywszego działania. W 2004 r., przy współudziale większości brytyjskich uniwersytetów, Rad Finansujących Edukację w Anglii, Walii, Szkocji i Irlandii Północnej oraz Agencji Ochrony Jakości dla Studiów Wyższych (Quality Assurance Agency), założono tzw. UK HE Europe Unit czyli Europejski Oddział Wyższego Wykształcenia Wielkiej Brytanii. Jest to pracownia monitorowania systemu szkolnictwa wyższego Wlk. Brytanii, która oprócz zdawania relacji z przebiegu ujednolicania procedur, zajmuje wiodące miejsce w promowaniu przemian europejskiej edukacji i poszukiwaniu możliwości zaangażowania w debatach i inicjatywach państw Procesu Bolońskiego.

Ważnym projektem dla Brytanii i jej prestiżu była propozycja Komisji Europejskiej w kolejnym aspekcie procesu bolońskiego, mianowicie zamiaru stworzenia Struktury Kwalifikacji Ustawicznego Nauczania w Europie (European Qualification Framework for Lifelong Learning tzw. EQF). Inicjatywa ta została bardzo dobrze przyjęta przez sektor edukacji na poziomie wyższym w Wlk. Brytanii, gdyż panuje tam przekonanie, że brytyjski program nauczania czyli 'curriculum' i jego wysoki standard są, jeśli nie najlepsze, to napewno jedne z najlepszych na świecie i z pewnością to Europa kontynentalna, według Brytyjczyków, ma do czego dorównywać w tym względzie. Trzeba tutaj zaznaczyć, że do pilnowania tego poziomu od strony państwa i społeczeństwa powstała w 1997r wymieniona już specjalna organizacja o nazwie Quality Assurance Agency for HE czyli Agencja Ochrony Jakości Studiów Wyższych.

Przejdźmy teraz do ukazania, jak wygląda struktura szkolnictwa wyższego na wyspach. W Anglii, Walii i Irlandii Północnej, instytucje tegoż szkolnictwa są niezależnymi, samorządnymi ciałami, aktywnymi w nauczaniu i badaniach. Powstawały dzięki edyktom królewskim lub zarządzeniom prawnym i większość z nich jest w części fundowana przez rząd. Wykształcenie wyższe może być uzyskane w różnych instytucjach. Oprócz uniwersytetów i uniwersyteckich college'ów, których statuty i edykty stworzone przez Tajną Radę Królewską, doradzającą panującej Królowej włączenie lub nie do znamienitego grona, jest wiele innych pań-

\footnotetext{
12 Polityka edukacyjna i standardy w Procesie Bolońskim (Bologna Process. Educational Policy and standards) http://www.admin.ox.ac.uk/epsc/bologna.shtml.
} 
stwowych instytucji reprezentujących szkolnictwo wyższe. Pozwolenie na państwowe finansowanie edukacji na poziomie wyższym w tzw. colleg'ach dalszej nauki, jest udzielane autorytetem należycie upoważnionej instytucji. Nauka przygotowująca studenta do otrzymania Dyplomu wyższego wykształcenia jest możliwa w każdej instytucji studiów wyższych, oraz niektórych Further Education College's (Uczelni dalszej nauki) ${ }^{13}$. Szkocja, której tu nie wymieniłem, ma nieco inną strukturę, ale w większości jest podobna do pozostałych trzech krajów brytyjskich wysp. Nie będę więc omawiał tego modelu, aby nie komplikować toku wywodów. A oto struktura studiów wyższych w Wlk. Brytanii ${ }^{14}$ : (Diagram na końcu w PDF) Na diagramie tym możemy zaobserwować dwa bloki edukacji wyższej. Po lewej stronie mamy typowe naukowe stopnie takie jak Doktor, Magister, Magister wielu nauk, Licencjat z wyróżnieniem, Dyplom Absolwencki itd, a po prawej stronie mamy kwalifikacje zawodowe od poziomu 3-ego aż do 8-ego. Ważne jest, aby zaobserwować, że np. poziom 8-my kształcenia zawodowego czyli kształcenia w miejscu zatrudnienia jest równy naukowemu doktoratowi, co oznacza że jeśli pracodawca daje takie możliwości i jest odpowiednie pole do rozwoju i treningu w firmie, to nie trzeba kończyć studiów i mieć porównywalny stopień zawodowy oraz płace. To samo tyczy się innych poziomów kwalifikacji zawodowej.

Spójrzmy obecnie na szkolnictwo wyższe w Wlk. Brytanii z punktu widzenia szczególnie interesujących danych statystycznych i porównajmy je z Polską i innymi krajami Procesu Bolońskiego. Po pierwsze liczba studentów i ich procent w społeczeństwie:

13 Further Education College's to uczelnie występujące w Wlk. Brytanii i Irlandii. Są one pewnego rodzaju alternatywą dla nieobowiązkowej edukacji po 16 roku życia, w stosunku do uniwersytetów. Opcja ta jest realizowana od najprostszego przyuczenia do zawodu aż do Narodowych Dyplomów Edukacji na Wyższym poziomie (Higher National Diploma). Uczelnie te są w pewnym sensie porównywalne do naszych szkół zawodowych i techników, gdyż wraz z przyuczeniem do zawodu mogą przygotowywać do studiów na uniwersytetach. Różni je jednak większa elastycznosć przy wyborze przedmiotów podczas nauki oraz, zbliżony do uniwersyteckiego, akademicki styl nauczania. (http://en.wikipedia.org/wiki/Further_education and http://www. europeunit.ac.uk/sites/europe_unit2/resources/EWNI.pdf).

Głównymi prawami i dekretami zarządzającymi Wyższym Wykształceniem w Wlk. Brytanii są: Education Reform Act z 1988 (Ustawa o reformie oświaty), Further and Higher Education Act z 1992 (Ustawa o Dalszej i Wyższej Edukacji), Higher Education Act z 2004 (Ustawa o szkolnictwie wyższym). 
Tabela 1. (Dane z 2005/06 r.)

\begin{tabular}{|c|c|c|c|}
\hline Kraj & Liczba studentów & Populacja kraju & $\begin{array}{c}\text { Procent studentów } \\
\text { w populacji }\end{array}$ \\
\hline Grecja & 653003 & 11103965 & 5.9 \\
\hline Litwa & 198868 & 3414304 & 5.8 \\
\hline Niemcy & 2289465 & 82437995 & 2.8 \\
\hline Polska & 2145687 & 38165445 & 5.6 \\
\hline Rosja & 9684755 & 143953092 & 6.7 \\
\hline Szwecja & 422614 & 9029572 & 3.9 \\
\hline Wlk. Brytania & 2336108 & 60242843 & U. \\
\hline
\end{tabular}

Źródło: Universities UK, Patterns of higher education institutions in the UK: Ninth report s. 50 (opr. własne).

Jak widać z tabeli nr 1, liczba studentów i ich procent na wyspach brytyjskich utrzymuje się na poziomie prawie $4 \%$ procent populacji, co w krajach rozwiniętych, gdzie istnieją większe możliwości pracy fizycznej zapewniającej byt na minimalnym poziomie, jest normalnym zjawiskiem. W strefie krajów rozwijających się, do których należy Polska, wielkość ta jest średnio o 1-2 punkty procentowe wyższa.

Jak wiemy w 2000r w Lizbonie, państwa omawianego procesu przyjęły, iż w ciagu 10 lat zwiększą swoje wydatki na wyższe wykształcenie do 3\% PKB i w ten sposób stworzą, konkurencyjny wobec Azji i Ameryki, Europejski Obszar Szkolnictwa Wyższego. Niestety nie udało się tych planów wypełnić po pierwsze przez sytuację ekonomiczną na świecie, ale również z uwagi na powszechnie zauważalny wewnętrzny opór wobec tego typu ujednolicania rynków poszczególnych państw. Procentowy udział tych kosztów w budżetach niektórych krajów partycypujących w procesie jest zamieszczony w tabeli nr 2.

Jedyne kraje, które w poważny sposób potraktowały postanownienia Strategii Lizbońskiej to Danie, Finlandia i Szwecja, więc nie może być jak na razie mowy o skutecznym rozwoju tej jakże ważnej dziedziny gospodarki w całym organizmie europejskim. Polska i Wlk. Brytania plasują się na tym samym, średnim, poziomie co dla naszego kraju powinno być bardzo pozytywnym zjawiskiem. Niestety jak pokaże tabela nr 3.

Jeżeli chodzi o implementacje zasad procesu bolońskiego w Zjednoczonym Królestwie na poziomie studiów doktoranckich, to zauważono potrzebę takiego rodzaju pracowników na ogólnym rynku pracy jak 
i oczywiście na uczelniach akademickich. Pracodawcy brytyjscy zaczynają rozumieć wartość takiego pracownika, domniemając, że posiada on wyższe umiejętności $\mathrm{w}$ rozwiązywaniu problemów oraz determinację w przełamywaniu, zwłaszcza przy pierwszych nieudanych próbach.

Tabela nr 2. (dane z 2005 r.)

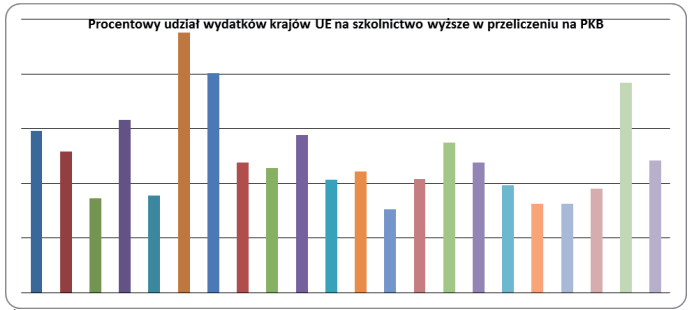

Źródło: Universities UK, Patterns of higher education institutions in the UK: Ninth report s. 65 (opr. własne).

Wielka Brytania i jej system nauczania na poziomie wyższym, umożliwia absolwentom wejście na rynek pracy już po pierwszym cyklu studiowania. Próbuje się to również - jako zasadę - wypromować na kontynencie. Dla brytyjskiego szkolnictwa liczy się przede wszystkim to, jak absolwenci dopasują sie do przyszłej pracy i jak najwcześniej mogą pracę rozpocząć. Tzw. licencjat jest bardzo popularny wśród pracodawców i nie żywią oni niechęci do studenta, który kończy naukę na tym etapie, wręcz przeciwnie twierdzą że 3 lata to wystarczający okres na przygotowanie do wdrażania teorii w praktykę. Według statystyk agencji zajmującej się studiami wyższymi (HESA), w 2004/2005 od 63\% do 66\% absolwentów, których drogi po studiach były znane, znalazło zatrudnienie, z tego 54\% w wyuczonym zawodzie. W Zjednoczonym Królestwie istnieją tzw. Rady Umiejętności (Sector Skills Councils), kierowane przez pracodawców, które współpracując ze związkami zawodowymi, rządem, stowarzyszeniami i pracodawcami określają, jakie umiejętności są potrzebne na rynku i w jakie należy inwestować na uniwersytetach. Wszystko to wyraźnie pokazuje, że Wyspy Brytyjskie są, i chcą być jeszcze bardziej, konkretne w kształceniu studentów. Liczą się przede wszystkim umiejętności, które nabywane podczas studiów wraz z wiedzą mają pomóc w konkretnym 
zawodzie, stanowisku pracy. Zbędna wiedza przekazywana na studiach to wręcz 'grzech' straty czasu każdej osoby uczestniczącej w zajęciach, profesora także w to wliczając. Każde seminarium lub egzamin ma mieć swój konkretny i praktyczny cel. To, z czego i w jaki sposób student jest egzaminowany, ma na wyspach określony zamiar nakierowania go na późniejsze uczenie się. Wymienione powyżej różnice w programach i sposobach nauczania w Zjednoczonym Królestwie i np. w Polsce mogą być nazwane nieistotnymi, ale już sposób oceniania studenta na egzaminie poprzez test jest ogromnie ważny, gdyż zapobiega on wszelkim niejasnościom i stronniczości pracowników naukowych, która się przecież ma prawo zdarzyć. Ściśle rzecz biorąc Brytyjczycy wyznaczają jasne cele i kryteria testu w skali od 0 do $100 \%{ }^{15}$. Aby zaliczyć trzeba osiągnąć określoną liczbę punktów, a nie odpowiednio, pozwolę sobie na to wyrażenie, „oczarować” profesora. Cele, których się nie da określić nie są dla studentów mobilizacją, a wręcz przeciwnie, zniechęceniem i poczuciem oszukania. I w dodatku ciężko się od tego systemu odwołać.

W podsumowaniu chciałbym wskazać na jeszcze dwa ważne aspekty edukacji brytyjskiej. Profesorowie, studenci oraz politycy spoza Zjednoczonego Królestwa nie mogą nadziwić systemowi krótszego studiowania jaki jest obecny w tamtym państwie. Nie jest tajemnicą, że skracanie czasu studiów nie podoba się w wielu kręgach profesorskich, gdyż za tym idą konkretne godziny pracy ze studentami, których może brakować do tzw. całego etatu. Co prawda Wielka Brytania nie jest krajem przodującym w zatrudnianiu pracowników akademickich na pół-etatu (w niepełnym wymiarze), ale jest wśród większości państw europejskich, które ten trend promują. Jest to trend zatrudniania profesora, doktora czy magistra tylko do takiej pracy na uczelni, do jakiej się najlepiej nadaje, czyli nie ma tam praktycznie żadnego zapychania dziur, aby tylko dać komuś godziny pracy. Sprawia to pracownikom naukowym duże trudności w znalezieniu jednego miejsca pracy, ale daje studentom tylko i wyłącznie konkretną wiedzę od konkretnego eksperta, a przecież na przekazaniu najlepszej wiedzy studentom powinno każdej uczelni zależeć. Drugi aspekt dotyczy czasu spędzonego przez studenta na zajęciach i wykładach, co jest problemem już od szkoły podstawowej, poprzez kolejne stopnie nauczania. Każda szkoła, do której przyszli studenci uczęszczają monitoruje każdego ucznia i jego obecność. Jeśli uczeń 4 razy się spóźnił lub nie przyszedł do szkoły a nie był chory, to wtedy rodzice są wzywani przed sąd i zwykle zostają skazani do zapłacenia wysokiej kary pieniężnej. Taki przyszły

15 Wywiad z Allison Rhodes - przeprowadzony 5 lutego 2010 r. (arch. własne). 
student już ma wyuczony nawyk koniecznej obecności na zajęciach i nie trzeba prowadzić tzw. specjalnych dyżurów, na których mógłby się on wykazać co było omawiane, kiedy go nie było. Te i inne jeszcze sposoby brytyjskiego nauczania sprawiają, że z powodzeniem jest możliwe nawet dwuletnie wyuczenie licencjata gotowego do pracy w swoim zawodzie. Dlatego realizacja idei Ruchu Bolońskiego w Wlk. Brytanii, zależy i będzie moim zdaniem zależała od tego czy inne kraje będą się długo upierały przy swoich systemach czy współpracując zdecydujemy się na 'Learning Outcomes', czyli kształcenie konkretnych umiejętności.

Zrozumiałe jest $\mathrm{w}$ tej sytuacji upieranie się przy swoich dobrze sprawdzonych metodach pracy w szkolnictwie wyższym każdego z partycypujących w systemie bolońskim państwie. Żaden z krajów nie chce tak łatwo poddać się temu, co może i jest lepsze lub takim się może wydawać, ale co sprawia, że w jakimś sensie inne narody czują się 'sterowane' w dziedzinie, która przecież powinna być niezależna od wszelkich wpływów. Zdania o imperializmie lub nacisku z zewnątrz, są w tej czy innej formie wypowiadane przez grupy profesorskie lub zwłaszcza studentów. Ci ostatni mają w wielu przypadkach dość nadmiernej ilości godzin nauki i pisania prac końcowych w dużo krótszym czasie niż przed systemem bolońskim.

Jest mało prawdopodobne, by coś zatrzymało ten 'walec' reform edukacyjnych w Europie, który jest konieczny z punktu widzenia zwiększania konkurencyjności i jedności kontynentalnej. To co jednak jest w tym wszystkim ważne, to zachowanie pewnej różnorodności w trakcie unifikowania struktur nauczania ze świadomością, że Wielka Brytania oprócz dobrych rad, sama powinna przyjmować porady ${ }^{16} \mathrm{z}$ kontynentu, aby zachować balans wymiany.

16 Najważniejsza to opisywane już wyżej problemy w zakresie nauki języków obcych w podstawówkach i tamtejszych gimnazjach, a w zasadzie notoryczne „wypychanie” ich z brytyjskiego Curriculum (program nauczania). 


\section{Abstract}

The article describes special presence of the Bologna Process in the body of United Kingdom. In the introduction we are told that since UK was an Empire until late 60 's of the $20^{\text {th }}$ century their political, linguistic and cultural dominance did not ceased suddenly at that time but continues to spread in different forms.

The education, a very important factor of a proper development of economy, seems to be the place where UK would like to keep their solid, internationally acclaimed, stance. Therefore, to the surprise of many European professors, for the last 10 years continental Higher Education is being reconstructed according to the British standards.

The main article portrays the Bologna Process from its beginning with an impact on its roots within the UK Higher Education. The special presence of the process in the UK is visible in the UK Europe Unit which basically stands for the centrally organised and supervised education department that is based on the continent and has the task of promoting the British way of changing the Higher Education in Europe and further to the World.

The article gives many examples of appropriate solutions that UK Higher Education invented and that could be or are implemented onto the broader scale like dividing all the academic teaching into stages (Bachelor, Master and Doctorate) or shortening the stages of teaching so the students could quicker enter the status of employee.

In the next part of the article we can compare the countries that take part in Bologna Process in the context of their expenditure in Higher Education with a pressure on researches and development. The particular examination has been taken on the examples of Poland an UK.

The paper concludes with a paragraphs explaining why, although it is difficult for some to accept it, the changes in the education are taking place anyway. 